\title{
IS ANTENATAL ADMINISTRATION OF RETINOIC ACID EFFECTIVE ON PULMONARY DEVELOPMENT IN PRETERM MICE WITH HYPOXIA-INDUCED INTRAUTERINE GROWTH RESTRICTION?
}

\author{
E. Tutdibi ${ }^{1}$, D. Monz ${ }^{1}$, L. Hert ${ }^{1}$, M.W. Laschke ${ }^{2}$, T. Tschernig ${ }^{3}$, L. Gortner ${ }^{1}$ \\ ${ }^{1}$ Department of Neonatology, ${ }^{2}$ Institute for Clinical and Experimental Surgery, ${ }^{3}$ Institute of Anatomy, \\ University of Saarland, Homburg, Germany
}

Background: Preterm newborns with intrauterine growth retardation (IUGR) are at increased risk for the development of pulmonary disorders. Vitamin A and its active form, all-trans retinoic acid (ATRA), are essential for growth and development of cells and tissues. Retinoids play an important role in the lung and respiratory epithelium. The fetal lung maturation has been demonstrated to be enhanced by vitamin A supplementation in animal models.

Aim: We tested the hypothesis whether antenatal administration of ATRA effects the fetal lung development in preterm mice with IUGR.

Methods: We exposed date-mated pregnant C57BL/6 mice (Charles River, Sulzfeld, Germany) by chance to hypoxia $\left(\mathrm{FiO}_{2} \mathrm{0.10}\right)$ or to normoxia starting from gestational day 14 (E14). On day E15 the animals were randomly allocated to receive intraperitoneally a single dose of ATRA $(10 \mathrm{mg} / \mathrm{kg})$ or its solvent $(0.1 \mathrm{ml} / \mathrm{kg}$ oil). Newborns were delivered preterm at day E17.5. Fetal lungs tissues were used for histomorphometric analyses. Expression of surfactant proteins (SP)-B and C was determined by quantitative real-time PCR as biochemical indicators for lung maturation.

Results: Histomorphometric analyses revealed no differences between groups. The mRNA expression of surfactant proteins was found to be without significant difference between newborns with IUGR and normoxia controls. However, treatment with ATRA increased significantly the pulmonary expression of SPB and SP-C by the factor of 1.8 in the normoxia group [ $<<0.01]$.

Conclusion: Maternal hypoxia led to IUGR in preterm mice without histomorphometric or transcriptional alterations of lung development. Antenatal treatment with ATRA effects SP gene expression in nonrestricted newborns. 